\title{
Risk Factors for Multidrug-resistant Pseudomonas aeruginosa Among Hospitalized Patients at a Malaysian Hospital
}

(Faktor Risiko Daya Tahan Multidrug dalam Kalangan Pesakit yang Dimasukkan ke Hospital di Malaysia)

\author{
M.D. MOHD NASIR, M.H. NURNAJWA, J. LAY, J.C.TEOH, A.N. SYAFINAZ \& M.T. NIAZLIN*
}

\begin{abstract}
A case-control study was conducted based on medical cases of 100 hospitalized patients with Pseudomonas aeruginosaisolation at a Malaysian hospital. Cases with 50 multidrug-resistant $\mathrm{P}$. aeruginosa MDRPA and 50 non-multidrug-resistant P. aeruginosa (NMDRPA) were randomly included and compared with socio-demographic and clinical data of the patients, using Chi-square and Fisher's exact tests as the statistical tool. Analysis found no significant association between MDRPA with ages, gender and ethnicity of patients ( $\mathrm{p}>0.050)$. Other risk factors being investigated were invasive procedure, immunosuppression, bedridden and clinical diagnosis such as central nervous- and respiratory-system disorder, as well as antibiotic exposure during hospitalization and duration of hospital stay with only the last two were found to have significant association ( $\mathrm{p}=0.035$ and 0.019 , respectively). Some other studies also reported a similar association indicating that the two factors could serve as an important predictive tool for isolation of MDRPA. More studies involving a larger sampling size are warranted to establish the association.
\end{abstract}

Keywords: Antibiotic exposure; hospital stay; multidrug resistant Pseudomonas aeruginosa; risk factor

\section{ABSTRAK}

Kajian secara kes kawalan ini dijalankan ke atas 100 kes pesakit yang dimasukkan ke hospital yang mengidap jangkitan Pseudomonas aeruginosa di Malaysia. Secara rawak 50 kes multidrug rintangan P. aeruginosa dan 50 kes tiada multidrug rintangan $\mathrm{P}$. aeruginosa dibandingkan secara sosio-demografik dan data klinikal pesakit menggunakan 'Chi-square' dan 'Fisher's exact tests' sebagai kaedah statistik. Analisis tersebut tidak menunjukkan hubungan yang signifikan dengan umur, jantina dan etnik pesakit ( $\mathrm{p}>0.050$ ). Faktor risiko lain yang dikaji adalah prosedur invasif, kekurangan imun, terlantar di katil dan diagnosis klinikal seperti sistem saraf dan pernafasan, pendedahan kepada antibiotik ketika berada di hospital dan tempoh tinggal di hospital. Keputusan kajian menunjukkan hanya dua faktor mempunyai hubungan signifikan (masing-masing $\mathrm{p}=0.035$ dan 0.019). Beberapa kajian lain juga turut melaporkan keputusan yang sama; yang menunjukkan bahawa kedua-dua faktor boleh bertindak sebagai faktor penyebab daya tahan multidrug P. aeruginosa. Lebih banyak kajian yang melibatkan saiz sampel yang lebih besar diperlukan untuk memperkukuhkan lagi hubungan tersebut.

Kata kunci: Daya tahan multidrug Pseudomonas aeruginosa; faktor risiko; pendedahan antibiotik; tempoh tinggal di hospital

\section{INTRODUCTION}

$P$. aeruginosa is a ubiquitous and opportunistic gram negative bacterium. In hospital setting, it is widely associated with nosocomial infection (Idris et al. 2012). Over the years, the isolation of multidrug-resistant $P$. aeruginosa (MDRPA) isolates from hospitalized patients has been increasingly reported, especially in the critically ill patients (Aloush et al. 2006; Hsu et al. 2005; Maruyama et al. 2013; Padmakrishnan et al. 2009). This leads to the severe adverse outcomes of the infection due to limited availability of antimicrobial agents for treatment. Therefore, pattern of potential risk factors for isolation of MDRPA among the hospitalized patients would be of significant interest to assess the precautionary measures and empirical antibiotic therapy. This study was undertaken to preliminarily identify the risk factors among patients at one of the major hospitals in Malaysia, Hospital Kuala Lumpur.

\section{MATERIALS AND METHODS}

This was a case-control study conducted on medical cases of 100 hospitalized patients with P.aeruginosa-isolation at Hospital Kuala Lumpur in year 2010 and 2011. With the exception of the antibiotic susceptibility status of the $P$. aeruginosa isolates, inclusion of cases was based on blind and random basis for all the potential risk factors being studied. Firstly, the result of disc diffusion sensitivity test of $P$.aeruginosa isolates from the hospitalized patients was retrieved in the microbiology laboratory at the Department of Pathology to include 50 MDRPA and 50 non-multidrugresistant $P$. aeruginosa (NMDRPA). The criterion for the 
MDRPA was isolates demonstrating resistance against at least two of the five anti pseudomonal classes of antimicrobial drugs tested on the isolates: piperacillintazobactam, cephalosporin, carbapenem, aminoglycoside and fluoroquinolone. A profoma was then used to further retrieve other necessary information from the patient's case notes in the Record Unit of the hospital. Information consisted of socio-demographic data such as age, gender and ethnicity of the patients, as well as other clinical information to be identified as risk factors for isolation of MDRPA in this study. Acquisition of data was in line with the research and ethical approval by the Faculty of Medicine \& Health Science's ethical committee, Universiti Putra Malaysia and Hospital Kuala Lumpur. For statistical analysis, Chi-square or Fisher's exacts test were used to determine association in the categorical distribution with significant level set at $p<0.050$.

\section{RESULTS}

Table 1 shows the distribution of socio-demographic factors in relation to isolation of MDRPA among the hospitalized patients. For simplicity of analysis, classification for ages and ethnic was sorted as below and above 54 years old and Malay or non-Malay. As for gender, male patients were found to double the number of female. Nonetheless statistical analysis showed no association $(p>0.050)$ in all the categories.

Seven clinical elements were identified as potential risk factors in this study as listed in Table 2. These factors were referred as non-socio-economic samples and analyzed in respect to the isolation of MDRPA regardless of the socioeconomic background of the hospitalized patients. Those are antibiotic exposure during hospitalization (cefuroxime, cloxacillin, ceftriaxone, ciprofloxacin and vancomycin), undergoing invasive procedure (nasograstic feeding and urinary catheter), duration of hospital stay (below and above 33 days), immunosuppression (on steroid, cancer, diabetes and undergoing organ transplant), bedridden patients and clinical diagnosis; central nervous-(CNS) and respiratory-system disorder (RS). Among the 100 samples, Table 2 shows variable distributions of the factors except for the bedridden patients which are about equal ( $\sim 50 \%$ each). Meanwhile, majority of the sample underwent invasive procedures $(99 \%)$ and had no clinical diagnosis for RS disorder (85\%) to assume low reliability in the subsequent comparative analysis. These two factors showed no significant association as expected. While for the rest, the associated frequency of MDRPA was also negligible except for the antibiotic exposure and hospital stay ( $p=0.035$ and 0.019 , respectively).

\section{DISCUSSION}

The risk factors that are included in this study have also been investigated by many other researchers but whether those were significantly associated with the isolation of MDRPA had been differentially reported (Aloush et al. 2006; Bahmani \& Ramazanzadeh 2013; Gibu et al. 2010; Hsu et al. 2005; Lodise et al. 2007; Shanthi \& Sekar 2009). These are due to the variability in the socio-economic and health status of the studied population, as well as sample size in the respective study's setting. This current data represents scenario at a major referral hospital in Malaysia which serves the crowded population of the metropolitan city of Kuala Lumpur ranging from all classes of occupation. As for the socio-economic background such as gender, ethnicity and age, the different groups may have different body metabolism and probably lifestyle to favor acquisition of $P$. aeruginosa or MDRPA and this would be too complex to be elucidated. On the other hand, the non-socio-economic factors alone (Table 2) could impose equal possibility for hospitalized patients in acquiring the isolates as they are all exposed to hospital environment. But if the socio-economic factors do have certain tendency for isolation of MDRPA, they could also be analyzed in respect to the non-socio-economic factors for a more comprehensive comparison. Nevertheless, it requires a large number of samples to allow a reliable relationship between age, gender and race with each of the non-socio-economic factors. This study did not perform such a correlation due to limited sample size and analysis was done independently from the socio-economic factors.

The data on antibiotic susceptibility pattern for the individual $P$. aeruginosa isolates was based on disc diffusion method following the 2012-CLSI guidelines. Nonetheless, as those were treated as dependent variables

TABLE 1. Association of patients with isolation of MDRPA and NMDRPA in relation to socio-demographic factors

\begin{tabular}{llcccc}
\hline Factors & & $\begin{array}{c}\text { Total } \\
n=100\end{array}$ & $\begin{array}{c}\text { MDRPA } \\
n=50(\%)\end{array}$ & $\begin{array}{c}\text { NMDRPA } \\
n=50(\%)\end{array}$ & $p$-value* \\
\hline Age & $0-53$ & 52 & $24(48)$ & $28(56)$ & 0.423 \\
& $54-98$ & 48 & $26(52)$ & $22(44)$ & \\
Gender & Male & 68 & $34(68)$ & $34(68)$ & 1.000 \\
& Female & 32 & $16(32)$ & $22(32)$ & 0.317 \\
\multirow{2}{*}{ Ethnicity } & Malay & 49 & $27(54)$ & $28(56)$ & \\
& Non-Malay & 51 & $23(46)$ & & \\
\hline
\end{tabular}

*Chi-square 
TABLE 2. Association of patients with isolation of MDRPA and NMDRPA in relation to non-socio-demographic factors

\begin{tabular}{|c|c|c|c|c|}
\hline Factors & $\begin{array}{c}\text { Total } \\
n=100\end{array}$ & $\begin{array}{c}\text { MDRPA } \\
n=50(\%)\end{array}$ & $\begin{array}{c}\text { NMDPA } \\
\mathrm{n}=50(\%)\end{array}$ & $p$-value* \\
\hline \multicolumn{5}{|c|}{ Antibiotic exposure } \\
\hline Yes & 66 & $38(76)$ & $28(56)$ & 0.035 \\
\hline No & 34 & $12(24)$ & $22(44)$ & \\
\hline \multicolumn{5}{|c|}{ Invasive procedure } \\
\hline Yes & 99 & $50(100)$ & $49(98)$ & $0.500^{\mathrm{a}}$ \\
\hline No & 1 & 0 & $1(2)$ & \\
\hline \multicolumn{5}{|l|}{ Hospital stay } \\
\hline 1- 33 days & 67 & $28(56)$ & $39(78)$ & 0.019 \\
\hline$>33$ days & 33 & $22(44)$ & $11(22)$ & \\
\hline \multicolumn{5}{|c|}{ Immunosuppression } \\
\hline Yes & 39 & $23(46)$ & $16(32)$ & 0.151 \\
\hline No & 61 & $27(54)$ & $34(68)$ & \\
\hline \multicolumn{5}{|l|}{ Bedridden } \\
\hline Yes & 48 & $28(56)$ & $20(40)$ & 0.109 \\
\hline No & 52 & $22(44)$ & $30(60)$ & \\
\hline \multicolumn{5}{|c|}{ Clinical diagnosis-CNS } \\
\hline Yes & 35 & $19(38)$ & $16(32)$ & 0.529 \\
\hline No & 65 & $31(62)$ & $34(38)$ & \\
\hline \multicolumn{5}{|c|}{ Clinical diagnosis-RS } \\
\hline Yes & 15 & $8(16)$ & $7(14)$ & 0.779 \\
\hline No & 85 & $42(84)$ & $43(86)$ & \\
\hline
\end{tabular}

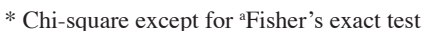

to include only MDRPA and NMDRPA, data on the antibiotic susceptibility of the isolates was not shown. In addition, the data on a proportion of the isolates has already been reported earlier (Idris et al. 2012). Validation by gold standard methods for a quantitative MIC value would provide a more reliable association rather than the terms MDRPA and NMDR alone. Last but not least, despite the limitations, the analysis in this current study offers a preliminary picture on potential association to call for a large scale-study, particularly the association of antibiotic exposure and duration of hospital stay which have been shown to be significant in this study. Other similar associations have also been reported by many studies regardless of the socio-economic factors of the studied sample (Aloush et al. 2006; Hsu et al. 2005; Lodise et al. 2007; Shanthi \& Sekar 2009). These can be undoubtedly understood as antibiotic exposure will cause selective pressure for MDRPA to proliferate while hospital stay will increase the likelihood of acquiring the nosocomial spread. Thus, these two factors can convincingly serve as an important predictive tool for MDRPA. Samples size need to be expanded to establish other potential risk factors as could they be the predictive tool as well.

\section{ACKNOWLEDGEMENTS}

We would like to thank Hospital Kuala Lumpur and the Faculty of Medicine \& Health Sciences, Universiti Putra Malaysia for giving the authorization to conduct this study.

\section{REFERENCES}

Aloush, V., Navon-Venezia, S., Seigman-Igra, Y., Cabili, S. \& Carmeli, Y. 2006. Multidrug-resistant Pseudomonas aeruginosa: Risk factors and clinical impact. Antimicrob. Agents Chemother. 50: 43-48.

Bahmani, N. \& Ramazanzadeh, R. 2013. Detection of SHV type extended-spectrum B-lactamase and risk factors in Pseudomonas aeruginosa clinical isolates. Pak. J. Med. Sci. 29: 788-792.

Ghibu, L., Miftode, E., Teodor, A., Bejan, C. \& Dorobăţ, C.M. 2010. Rev. Med. Chir. Soc. Med. Nat. Iasi. 114: 1012-1016.

Hsu, D.I., Okamoto, M.P., Murthy, R. \& Wong-Beringer,A. 2005. Fluoroquinolone-resistant Pseudomonas aeruginosa: Risk factors for acquisition and impact on outcomes. J. Antimicrob. Ther. 55: 535-541.

Idris, S.N.A., Desa, M.N.M., Aziz, M.N. \& Taib, N.M. 2012. Antimicrobial susceptibility pattern and distribution of ExoU and ExoS genes in clinical isolates of Pseudomonas aeruginosa at a Malaysian Hospital. Southeast Asian J.Trop. Med. Public Health 43: 116-123.

Lodise, T.P., Christopher, D.M., Jeffrey, G., Furuno, J.P., McGregor, J.C., Ben, L., Graffunder, E. \& McNutt, L.A. 2007. Clinical prediction tool to identify patients with Pseudomonas aeruginosa respiratory tract infections at greatest risk for multidrug resistance. Antimicrob. Agents Chemother. 51: 417-422.

Maruyama, T., Fujisawa, T., Okuno, M., Toyoshima, H., Tsutsui, K., Maeda, H., Yuda, H., Yoshida, M., Kobayashi, H., Taguchi, O., Gabazza, E.C., Takei, Y., Miyashita, N., Ihara, T., Brito, V. \& Niederman, M.S. 2013. A new strategy for healthcare-associated pneumonia: A 2-year prospective 
multicenter cohort study using risk factors for multidrugresistant pathogens to select initial empiric therapy. Clinical Infectious Diseases 57: 1373-1383.

Padmakrishnan, R.A., Murugan, T. \& Renuga Devi, M.P. 2009. Studies on multidrug resistant Pseudomonas aeruginosa from pediatric population with special reference to extended spectrum beta lactamase. Indian Journal of Science and Technology 2: 11-13

Shanthi, M. \& Sekar, U. 2009. Multi-drug resistant Pseudomonas aeruginosa and Acinetobacter baumannii infections among hospitalized patients: Risk factors and outcomes. J. Assoc. Physicians India 57: 638-640.

\section{M.D. Mohd Nasir}

Department of Biomedical Science

Faculty of Medicine \& Health Sciences

Universiti Putra Malaysia

43400 Serdang, Selangor D.E.

Malaysia
M.H. Nurnajwa, J. Lay, J.C. Teoh, A.N. Syafinaz \& M.T. Niazlin* Department of Medical Microbiology \& Parasitology Faculty of Medicine \& Health Sciences

Universiti Putra Malaysia 43400 Serdang, Selangor D.E.

Malaysia

*Corresponding author; email: niazlin@upm.edu.my

Received: 2 May 2013

Accepted: 5 August 2014 